\title{
CIRI KHAS STRUKTUR TAHANAN JENIS DI DAERAH PANAS BUMI TEMPERATUR TINGGI: STUDI KASUS DAERAH PANAS BUMI JABOI-PULAU WEH
}

\author{
Oleh: \\ Edi Suhanto, Sriwidodo dan Kasbani \\ Kelompok Program Penelitian Panas Bumi \\ Pusat Sumber Daya Geologi \\ SARI
}

Anomali tahanan jenis rendah yang teramati pada sistem panas bumi di lingkungan vulkanik sangat penting untuk menentukan targe-target eksplorasi. Anomali-anomali tahanan jenis secara umum memperlihatkan anomali rendah di suatu zona di atas resevoir panas bumi. Suatu model khas tentang struktur tahanan jenis dari daerah panas bumi di lingkungan vulkanik telah dikaji oleh beberapa ahli geofisika untuk mengerti faktor-faktor yang mempengaruhi tahanan jenis di daerah panas bumi, dimana memperlihatkan bahwa produk-produk lempung konduktif dari hasil alterasi hidrotemal adalah yang paling umum sebagai penyebab keberadaan tahanan jenis rendah di atas reservoir.

Penyelidikan tahanan jenis listrik dc Schlumberger telah dilakukan di daerah panas bumi Jaboi, Pulau Weh, Nangroe Aceh Darussalam pada tahun 2005. Hasilnya memperlihatkan suatu delineasi zona tahanan jenis rendah yang berkaitan dengan zona prospek panas bumi Jaboi. Pola sebaran lateral tahanan jenis memperlihatkan zona-zona outflow ke arah mata air panas Jaboi dan Keuneukai. Struktur tahanan jenis memperlihatkan suatu lapisan konduktif kaya mineral lempung berbentuk cendawan dimana puncaknya mendekat ke permukaan di bawah daerah fumarola Jaboi dan ke sisi-sisinya semakin mendalam, dengan ketebalan yang bervariasi antara $200 \mathrm{~m}$ di daerah fumarola sampai $1100 \mathrm{~m}$ jauh di luar fumarola. Hasil perbandingan memperlihatkan bahwa delineasi zona rendah dan kecenderungan bentuk anomali tahanan jenis daerah Jaboi ini mempunyai kemiripan dengan tipikal struktur tahanan jenis di daerah vulkanik bertempatur tinggi.

\section{ABSTRACT}

Low resistivity anomaly observatin in geothermal system of volcanic area becomes very important to define targets of exploration. In general, resisfivity anomalies indicated low anomaly on geothermal reservoir zone A nodel of resistivity has been assessed by geophysicists to find out factors influencing resistivity in geothermal zone. It is believed that products of conductive clay resulted from hydrothermal alteration causing the existing lower resistivityon the said reservoir:

Electric resistivity conducted by Schlumberger in Jaboi geothermal fied Aceh Darusslam in 2005 show'ed delineation of low resistivity. Lateral distribution of resistivity indicated outflow zones occurred to the geothermal springs of Jaboi and Keuneuka. Resistivity structure showed th existence of abundant clay on conductive layers in the form of parasiticon which its peak closer down below the fumarola of Jaboi and deeper to its rim with the thickness of $200 \mathrm{~m}$ in furmarola zones and about $1100 \mathrm{~m}$ farther out of fumarola. From the comparative study results showed the lower delineation zone and resistivity zone of Jaboi geothermal field tends to have similirity structural resistivity in high temperature volcanic area.

\section{PENDAHULUAN}

Tahanan jenis adalah salah satu sifat fisis batuan yang paling bervariasi dan telah terbukti sebagai parameter geofisika yang paling ampuh dalam eksplorasi panas bumi.

Pengukuran geolistrik tahanan jenis telah lama digunakan sebagai sebuah teknik ekslporasi geofisika dalam pencarian sumber daya panas bumi. Metode tahanan jenis semu arus searah (DC) telah banyak digunakan dalam prospek panas bumi di Indonesia dengan tingkat keberhasilan yang baik terutama pada daerah-daerah panas bumi yang berasosiasi dengan vulkanisme. Anomali-anomali tahanan jenis semu pada daerah-daerah ini secara umum mampu mendelineasi resevoir panas bumi bertemperatur tinggi. Oleh karenanya, anomali tahanan jenis semu secara umum diterima sebagai indikator terbaik bagi suatu target panas bumi.

Berikut adalah cuplikan-cuplikan tentang bagaimana sifat fisis tahanan jenis batuan dimengerti dalam eksplorasi panas bumi.

\section{Struktur Umum Tahanan Jenis Panas Bumi Temperatur Tinggi}

Johnston dkk. (1992) telah membuat studi untuk mengevalusi berbagai metode tahanan jenis untuk eksplorasi panas bumi di daerah berlingkungan vulkanik. Mereka menyimpulkan bahwa kontras-kontras tahanan jenis dapat mendelineasi reservoir panas bumi dengan resolusi dan level 
galat pengukuran yang baik. Mereka membuat struktur tipikal sebuah sistem panas bumi seperti ditampilkan secara skematik dalam Gambar 2. Zona-zona bagian atas yang lebih dingin dicirikan oleh alterasi ke smektit, suatu zona lempung konduktif (secara kelistrikan) yang terbentuk pada temperatur di atas $70^{\circ} \mathrm{C}$. Di bawahnya adalah zona-zona bertemperatur lebih tinggi dimana ilit yang sedikit kurang konduktif saling menjemari dengan smektit. Kedua zona alterasi ini umumnya membentuk suatu penudung (clay cap) bagi suatu sistem panas bumi. Proporsi ilit naik terhadap temperatur, membentuk sekitar $70 \%$ dari campuran lempung tadi pada temperatur $180^{\circ} \mathrm{C}$. Pada temperatur di atas $180^{\circ} \mathrm{C}$ ini kandungan smektit terus menurun, dan ilit murni muncul secara umum pada temperatur lebih tinggi daripada $220^{\prime \prime} \mathrm{C}$ bersainaan mineral-mineral alterasi bertemperatur tinggi lainnya (klorit, epidot, dsb.) dalam kelompok alterasi propilitik.

Tahanan jenis dari zona smektit secara umum antara 1 dan 10 Ohm-m, bergantung utamanya pada tipe dan intensitas alterasi dan dapat berubah terhadap derajat saturasi dan temperatur aktual. Pada temperatur yang lebih tinggi, tahanan jenis meninggi. Pada saat transisi proporsi smektit turun $30 \%$ yang berkorespondensi dengan temperatur sekitar $180^{\circ} \mathrm{C}$, tahanan jenis tipikal berada diantara 20 dan $100 \mathrm{Ohm}-$ $\mathrm{m}$. Sedangkan tahanan jenis di luar sistem panas bumi sangat bervariasi. Nilai 200 sampai $500 \mathrm{Ohm}-\mathrm{m}$ umum ditemukan di batuan vulkanik perınukaan baik kering maupun tersaturasi parsial. Namun demikian, kehati-hatian harus dilakukan terhadap keberadaan sedimen, terutama sedimen laut, yang dapat memiliki nilai tahanan jenis kurang dari $5 \mathrm{ohm}-\mathrm{m}$.

Daerah panas bumi Jaboi terletak di Pulau Weh yang secara administratif merupakan wilayah kota Sabang, Provinsi Nangroe Aceh Darussalam (Gambar 1). Pada tahun 2005 telah dilakukan pengukuran tahanan jenis dc dengan konfigurasi Schlumberger.

Pada tulisan ini anomali tahanan jenis rendah di daerah panas bumi Jaboi dianalisis untuk melihat batas-batas zona prospek. Struktur-struktur tahanan jenisnya dianalisis untuk melihat kemungkinan keberadaan parameterparameter reservoir seperti zona alterasi lempung dan puncak reservoir. Hasil ini akan diperbandingkan dengan suatu model tipikal tahanan jenis dari sistem panas bumi bertemperatur tinggi seperti dikutip di atas. Model struktur tahanan jenis Jaboi adalah tipikal dari sistem panas bumi temperatur tinggi di lingkungan vulkanik?

\section{TATANAN GEOLOGI DAN MANIFESTASI PANAS BUMI}

Pulau Weh merupakan sebuah pulau gunungapi muda yang terdiri dari deretan kerucut muda berarah baratlaut-tenggara dan utara-selatan (lihat Gambar 1). Pulau ini masih terletak pada bagian ujung baratlaut dari strukt depresi besar Sumatera atau "graben Semangko Karenanya, deretan kubah dan struktur-struktur sesar utam di pulau tersebut dominan berarah baratlaut-tenggar Sebaran batuan dapat dibagi dalam tiga satuan batuan: batua vulkanik tua Weh berumur Tersier-Kuarter, batuan vulkan muda Kuarter, dan batugamping Kuarter berada di bagi timurlaut pulau.

Manifestasi panas permukaan pada empa kelompok lokasi: di Jaboi berupa lapanga fumarola/solfatar/tanah panas dengan luas sekitar 12 dengan temperatur mencapai $99.5^{\circ} \mathrm{C}$ dan beberapa mata panas dengan $\mathrm{pH}$ netral dan temperatur antara 67 dan $71^{\prime}$ lapangan fumarola/solfatara ini terletak di lereng tengga gunungapi termuda G. Leumo Matee dan di lereng utara Semeureuguh yang berumur Kuarter; di Keunekai beru sebuah mata air panas $\mathrm{pH}$ netral dengan temperatur $38^{\circ} \mathrm{C}$; Lhok Pria Laot berupa tanah teralterasi, kolam lumpur pan dan mata air panas dengan temperatur mencapai $100^{\circ} \mathrm{C}$; di Iboih berupa mata air panas bertemperatur sekitar $41^{\circ} \mathrm{C}$.

\section{SEBARAN TAHANAN JENIS SEMU}

\section{Anomali Tahanan Jenis Semu Rendah}

Gambar 3 memperlihatkan sebaran tahanan je semu untuk bentangan setengah arus $(\mathrm{AB} / 2) 250 \mathrm{~m}$. Peta memperlihatkan secara menonjol suatu anomali tahan jenis semu rendah dengan bentuk menutup dan konsentrik arah area fumarola/solfatara Jaboi dan pada sisi tim melidah ke arah mata air panas pantai Jaboi. Kecenderung melidah juga terlihat pada sisi baratlautnya yang cenderu melidah ke arah selatan dimana mata air panas Keuneuk berada, namun kurang tegas. Pola kontur pada sekit anomali rendah ini memperlihatkan gradien yang teg kecuali di sisi timur yang difusif ke arah timur timu tenggara atau ke pantai timur Jaboi dimana beberapa mata panas Jaboi berada. Untuk mempermudah analisis, ga kontur 10 Ohm-m dipertegas dan diberi warna biru (Gamb 3), digunakan untuk memperlihatkan pola anomali menut $<10$ Ohm-m dan membatasi zona prospek bagian dal dilihat dari peta $A B / 2250 \mathrm{~m}$. Untuk selanjutnya kontur Ohm-m ini akan diperbandingkan dengan garis kontur Ohm-m untuk AB/2 yang lebih besar lainnya. Pada gamb tersebut juga diperlihatkan suatu daerah arsiran (selanjutn disebut ring) yang mengelilingi sisi luar garis kontur Ohm-m. Ring ini memiliki daerah arsiran yang sempit lebar tergantung dari gradien kontur dekat garis kontur Ohm-m, dimana sempit berarti gradiennya relatif tinggi ya juga berarti menandai batas anomali yang tegas sedangk lebar berarti sebaliknya, gradiennya relatif lebih rendah ya juga berarti menandai batas anomali yang tidak tegas a malah difusif jika lebih lebar lagi. Ring ini memperlihat 
struktur

batas anomali yang tegas keculali pada sisi timurnya yang cenderung difusif melidah ke arah timur timur-tenggara atau ke arah pantai Jaboi tempat dimana mata air-mata air panas Jaboiberada.

Sebaran tahanan jenis semu AB/2 $500 \mathrm{~m}$, seperti sebaran sebelumnya, juga memperlihatkan secara menonjol suatu anomali tahanan jenis semu rendah dengan bentuk menutup dan konsentrik ke arah lapangan fumarola/solfatara Jaboi (Gambar 4). Garis kontur 10 Ohm-m pada sebaran ini (warna hijau) memiliki bentuk yang mirip dengan garis kontur 10 Ohm-m pada $\mathrm{AB} / 2250 \mathrm{~m}$, namun sisi barat dan timurlautnya sedikit lebih meluas. Ring pada peta ini selain mempunyai sisi timurnya yang difusif ke pantai Jaboi, juga sisi baratlautnya yang difusif melidah ke selatan ke arah pantai Keuneukai dimana mata air panas Keuneukai berada. Secara umum, nilai tahanan jenis semu pada peta ini tertinggi sekitar 300 Ohm-m, atau lebih rendah daripada pada peta $\mathrm{AB} / 2250 \mathrm{~m}$ yang nialai tertingginya mencapai sekitar 800 Ohm-m.

Pada sebaran tahanan jenis semu AB/2 $750 \mathrm{~m}$ juga masih diperlihatkan suatu anomali rendah menonjol (Gambar 5) dengan bentuk yang sama seperti pada peta-peta sebelumnya. Garis kontur $10 \mathrm{Ohm}-\mathrm{m}$ pada sebaran ini (warna merah) memiliki bentuk yang mirip dengan garis kontur 10 Ohm-m pada $A B / 2500 m$, namun pada sisi baratlautnya jauh meluas dengan bentuk melidah ke selatan ke mata air panas Keuneukai, selain sisi timurlautnya yang juga sedikit meluas. Ring pada peta ini secara umum jauh lebih lebar atau kurang tegas daripada ring pada peta-peta sebelumnya; dan sisi timurnya masih difusif ke pantai Jaboi.

Pada sebaran tahanan jenis semu $\mathrm{AB} / 21000 \mathrm{~m}$ (Gambar 6) pola anomali rendahnya mirip dengan anomali rendah pada peta $A B / 2750 \mathrm{~m}$, dimana pada sisi baratlautnya garis kontur 10 Ohm-m (warna ungu) juga melidah ke selatan, yakni ke mata air panas Keuneukai namun dengan ujung lidahnya yang cenderung meluas ke tenggara, dan juga dengan sisi timunya yang lebih meluas ke tenggara. Ring pada peta ini juga mirip dengan ring pada $A B / 2750 \mathrm{~m}$, dimana secara umum jauh lebih lebar atau kurang tegas daripada ring pada peta-peta $\mathrm{AB} / 2500 \mathrm{~m}$ dan $250 \mathrm{~m}$. Pada sisi timurnya ring ini masih cenderung difusif ke pantai Jaboi.

\section{Delineasi Zona Prospek dan Struktur Outflow}

Gambar 7 memperlihatkan kompilasi garis kontur $10 \mathrm{Ohm}-\mathrm{m}$ hasil analisis dari masing-masing $\mathrm{AB} / 2250 \mathrm{~m}$, $500 \mathrm{~m}, 750 \mathrm{~m}$, dan $1000 \mathrm{~m}$ di atas. Secara umum semakin besar $\mathrm{AB} / 2$ semakin lebar garis konturnya. Dapat dilihat bahwa garis-garis ini saling berimpit relatif rapat di bagian baratlaut dan selatan. Ini mengindikasikan bahwa batas tepi zona rendah relatif tegas pada bagian-bagian tersebut. Pada bagian-bagian lain seperti di bagian utara dan timur garis- garis ini berimpit secara renggang atau mengindikasikan batas tepi zona rendah yang relatif kurang tegas. Pada bagian baratlaut, garis-garis AB/2 $250 \mathrm{~m}$ dan $500 \mathrm{~m}$ saling berdekatan dan jauh dari garis-garis $\mathrm{AB} / 2750 \mathrm{~m}$ dan $1000 \mathrm{~m}$ yang keduannya berdekatan dan melidah ke mata air panas Keuneukai.

Dari keempat garis kontur ini dibentuk sebuah ring (diperlihatkan oleh daerah berarsir pada Gambar 7) dengan lebar yang bergantung pada kerapatan keempat garis kontur tersebut. Ring ini dapat djjadikan sebagai alat untuk mendelineasi zona prospek; zona prospek berada dalam bagian dalam ring dan dalam ring tersebut. Sempit dan lebarnya ring mengindikasikan tegas atau kurang tegasnya batas tepi dari zona prospek atau mengindikasikan tingkat ketidakpastian batas tepi. Ring ini relatif sempit di sisi baratlaut dan selatan yang mengindikasikan bahwa batas tepi zona rendah relatif tegas pada bagian-bagian tersebut. Pada sisi utara dan timur ring relatif lebar yang mengindikasikan batas tepi zona rendah yang relatif kurang tegas. Pada sisi ini ring cenderung melidah ke arah pantai Jaboi tempat dimana mata air mata air Jaboi berada. Pada sisi baratlaut ring juga melebar dengan bentuk melidah ke selatan ke mata air Keuneukai di pantai Keuneukai.

Bentuk melidah dari ring merupakan tipikal suatu struktur 'outflow' dari sistem panas bumi, dimana fluida panas bumi dalam bentuk air panas keluar dari sistem ke dekat permukaan dengan arah yang dikontrol oleh arah radien hidrologi. Sebagian dari air panas ini keluar ke permukaan sebagai mata air panas. Untuk kasus prospek Jaboi ini, mataair panas di pantai Jaboi dan Keuneukai merupakan manifestasi panas yang berada pada struktur outflow dari sistem panas bumi Jaboi.

\section{STRUKTUR TAHANANJENIS}

\section{Struktur Perlapisan}

Struktur perlapisan tahanan jenis diperoleh dari hasil pemodelan sounding satu dimensi. Struktur tahanan jenis daerah panas bumi Jaboi secara umum memperlihatkan suatu pola $H$ (tinggi-rendah-tinggi) seperti kebanyakan daerah panas bumi lainnya. Pola ini terdiri dari lapisan pertama berupa overburden resistif dengan nilai antara 40 Ohm-m sampai 1500 Ohm-m, lapisan kedua berupa lapisan tahanan jenis rendah/konduktif dengan nilai antara $2 \mathrm{Ohm}-\mathrm{m}$ sampai $10 \mathrm{Ohm}-\mathrm{m}$, dan lapisan ketiga berupa lapisan dasar elektrik dengan nilai antara 15 Ohm-m sampai 25 Ohm-m. Ketebalan lapisan pertama bervariasi antara $0 \mathrm{~m}$ di daerah fumarola sampai $500 \mathrm{~m}$ jauh di luar fumarola. Ketebalan kedua atau lapisan konduktif bervariasi antara $200 \mathrm{~m}$ di daerah fumarola sampai $1100 \mathrm{~m}$ jauh di luar fumarola.

Gambar 8 memperlihatkan sebuah penampang struktur tahanan jenis yang memotong Keuneukai ke utara 
ai di komplek fumarola Jaboi, kemudian membelok ke ke komplek mata air panas Jaboi. Struktur tahanan ini membentuk pola payung cendavan dengan aknya pada daerah manifestasi fumarola dan menyentuh akaamnya. Semakin menjauh dari daerah fumarola, an konduktif semakin dalam dan menebal. Pada daerah ow atau komplek mata air panas Jaboi puncak, lapisan luktif berada pada kedalaman sekitar $500 \mathrm{~m}$ dengan balan sekitar $1000 \mathrm{~m}$. Pada daerah outflow Keuneukai lipisan konduktif memiliki pola dengan kecenderungan g sama.

\section{mukaan Lapisan Resistif}

Lapisan di bawah lapisan konduktif, berupa lapisan gan nilai sekitar antara 15 Ohm-m dan 25 ()hm-m, enali sebagai lapisan resistif, dan bertindak sebagai san dasar elektrik. Lapisan resistif ini kemungkinan asosiasi dengan zona reservoir bagian atas dari sistem as bumi Jaboi. Permukann lapisan konduktif, seperti isan konduktifnya, memiliki bentuk permukaan dawan dengan puncaknya berada pada kedalaman sekitar -300 $\mathrm{m}$ di bawah daerah fumarola dan mendalan ke arah r serta curam pada daerah outflow, terutama di outflow oi kedalamannya sekitar 1500-2000 m dari permukaan.

Gambar 9 memuat suatu pemukatan dasar lapisan aduktif atau permukain atas lapisan resistif, dioverlaykan gan anomali-anomali tahanan jenis semu dan batas zona spek. Kedalaman permukaan tersebut relatif terhadap mukaan tanah dengan nilai yang positif ke bawah. Kontur mukian ini memiliki bentuk yang cenderung konsentrik ngan pusat yang berada pada daerah tengah zona anomali adah dan dengan pola yang melidah ke baratlaut, mengikui ntuk melidah dari zona anomali rendahnya. Ke arah timuraggara, bentuk kontur tidak melidah mengikuti bentuk elidahnya anomali rendah namun berlineasi utara-baratlaut in menurun secara tajam mulai dari sekitar $500 \mathrm{~m}$ di barat mata air panas Jaboi ke arah pantai Jaboi. Ini memperlihatkan bahwa permukaan resistif di daerah tersebut curam dan semakin mendalam ke arah timur. Gambar 10 memperlihatkan gambaran 3-dimensi dari permukaan atas lapisan resistif.

\section{Perbandingan Struktur Tahanan Jenis}

Perbandingan struktur tahanan jenis Jaboi (Gambar 8) dengan tipikal struktur tahanan jenis Johnston, dkk. (1992) memperlihathan kemiripan bentuk, terutama diperlihatkan oleh lapisan tahanan jenis rendahnya yang berbentuk cendawan yang memiliki ketebalan bervariasi antara $200 \mathrm{~m}$ di daerah fumarola sampai $1100 \mathrm{~m}$ jauh di luar tumarola. Lapisan rendah yang memiliki tahanan jenis bervariasi antara 2 s.d. $80 \mathrm{hm}-1 \mathrm{~m}$ ini berkaitan dengan lapisan clay capnya Johnston, dkk. (1992) yang kaya mineral smektit dau campuran smetit-ilit yang merupakan mineral-mineral alterasi hidrotermal. Pada batas permukaan bawah lapisan konduktif ini atau batas atas lapisan resistif (Gambar 9 dan 10) dapat diharapkan untuk mempunyai temperatur lebih besar daripada $180^{\circ} \mathrm{C}$, dan di dalam lapisan resistif yang memiliki tahanan jenis bervariasi antara 10 s.d. 25 Ohm-m ini dapat diharapkan untuk mempunyai temperatur lebih besar daripada $220^{\circ} \mathrm{C}$.

\section{KESIMPULAN}

Sebaran lateral tahanan jenis mendelineasi suatu batas prospek panas bumi Jaboi dengan bentuk yang menutup dengan pusatnya di sekitar fumarola dan pola-pola lidahnya yang menggambarkan dua zona outflow ke arah pantai Jaboi dan pantai Keuneukai.

Struktur tahanan jenis memperlihatkan suatu struktur cendawan yang memiliki kemiripan dengan ciri khas struktur tahanan jenis di daerah panas bumi suhu tinggi berlingkungan vulkanik. Diperkirakan reservoir utama darl sistem Jaboi ini akan lebih chekat permukaan di daerah sekitar fumarola Jaboi dan semakin mendalam menjauhinya.

\section{AFTAR PUSTAKA}

nderson E., Crosby D., and Ussher G (2000). Bull-eye Simple resistivity imaging to reliably loCate the geothermal reservoir. ProCeeding World Geothermal Congress 2000.

anwell, C. J. and Macdonald,W.J.P, 1965. Resistivity surveying in New Zealand themal areas. Commonivealth Mining and Metallurgical Congress, Australia and New Zealand, New Zealand Section pp 1-7.

ohnston, J.M., Pellerin, L. and Hohmann, G.W. (1992). Evaluation of electromagnetic methods for geothermal reservois detection. Geothermal Resources Council Transaction, Vol. $16 \mathrm{pp} 241-245$

isk. 1986. Reconnaissance and follow-up resistivity surveying of New Zealand geothermal fields. ProC. 8th New Zealand Geothermal Workshop 1986, pp 75-80.

uhanto, E. and Soemantri, M., 2003. Geophysical study of Mangolo geothemal field, Kolakia Southeast Sulawesi. ProC. 6th Annual Converence of INAGA 2003.

ssher G., Harvey C., Johnstone R., and Anderson E. (2000). Understanding the resistivities observed in geothermal systems

ProCeeding World Geothermal Congress 2000. 
ihatkan am dan oar 10 an atas Jaboi ohnston, erutama va yang ervariasi h di luar an jenis lapisan smektit -mineral lapisan ar 9 dan ul lebih tif yang im-m ini ih besar ola-pola ke arah n suatu cirikhas ul tinggi ama dari h sekitar reservoif ning and reservoil - Zealand roC. 6 system

Gambar 1. Sebaran manifestasi panas bumi, sebaran batuan, batas daerah penyelidikan Jaboi, dan indeks lokasi penyelidikan tahanan jenis di Pulau Weh, Kota Sabang, Nangroe Aceh Darussalam.

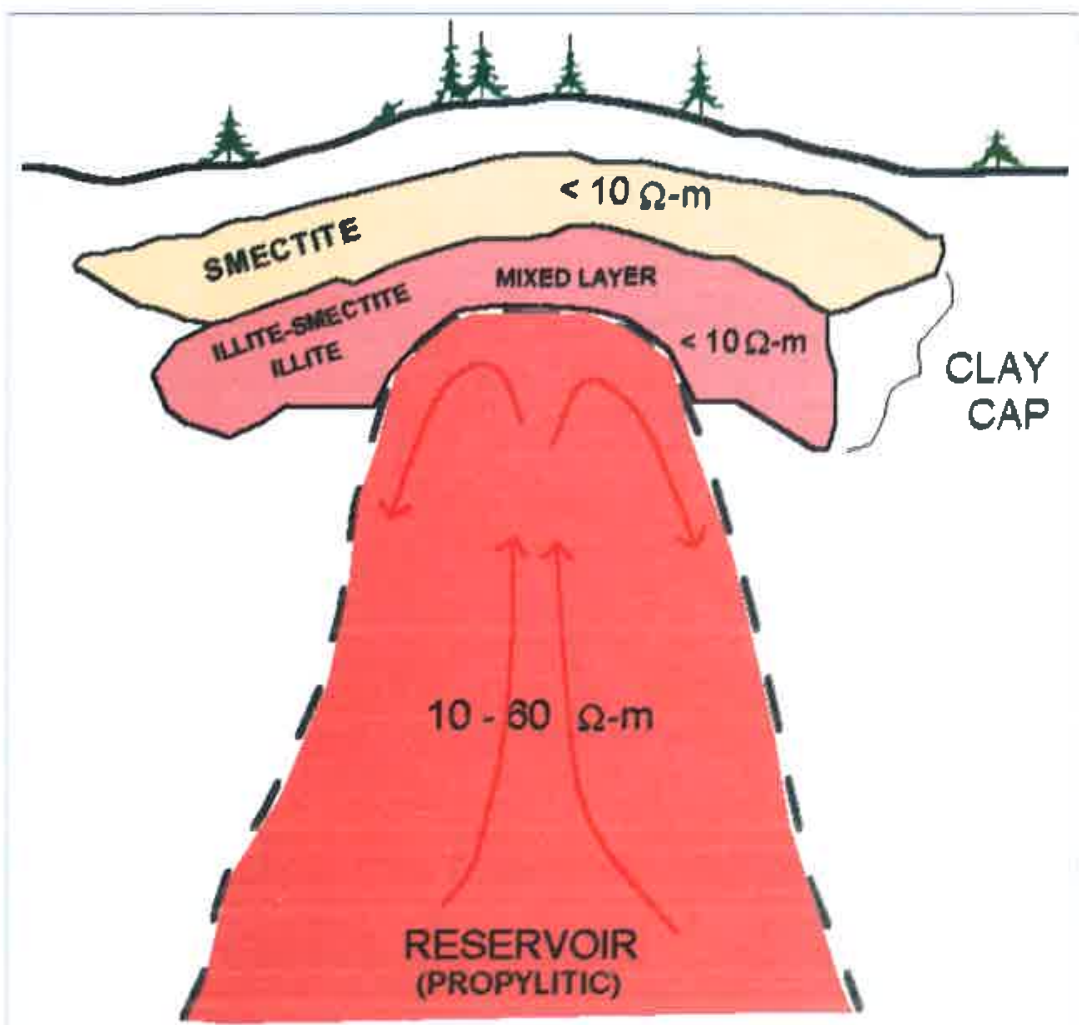

Gambar 2. Model tipikal/khas struktur tahanan jenis pada lapangan panas bumi temperatur tinggi di daerah vulkanik dan hubungannya dengan jenis mineral alterasi (diambil dari Johnston, dkk. 1992). 


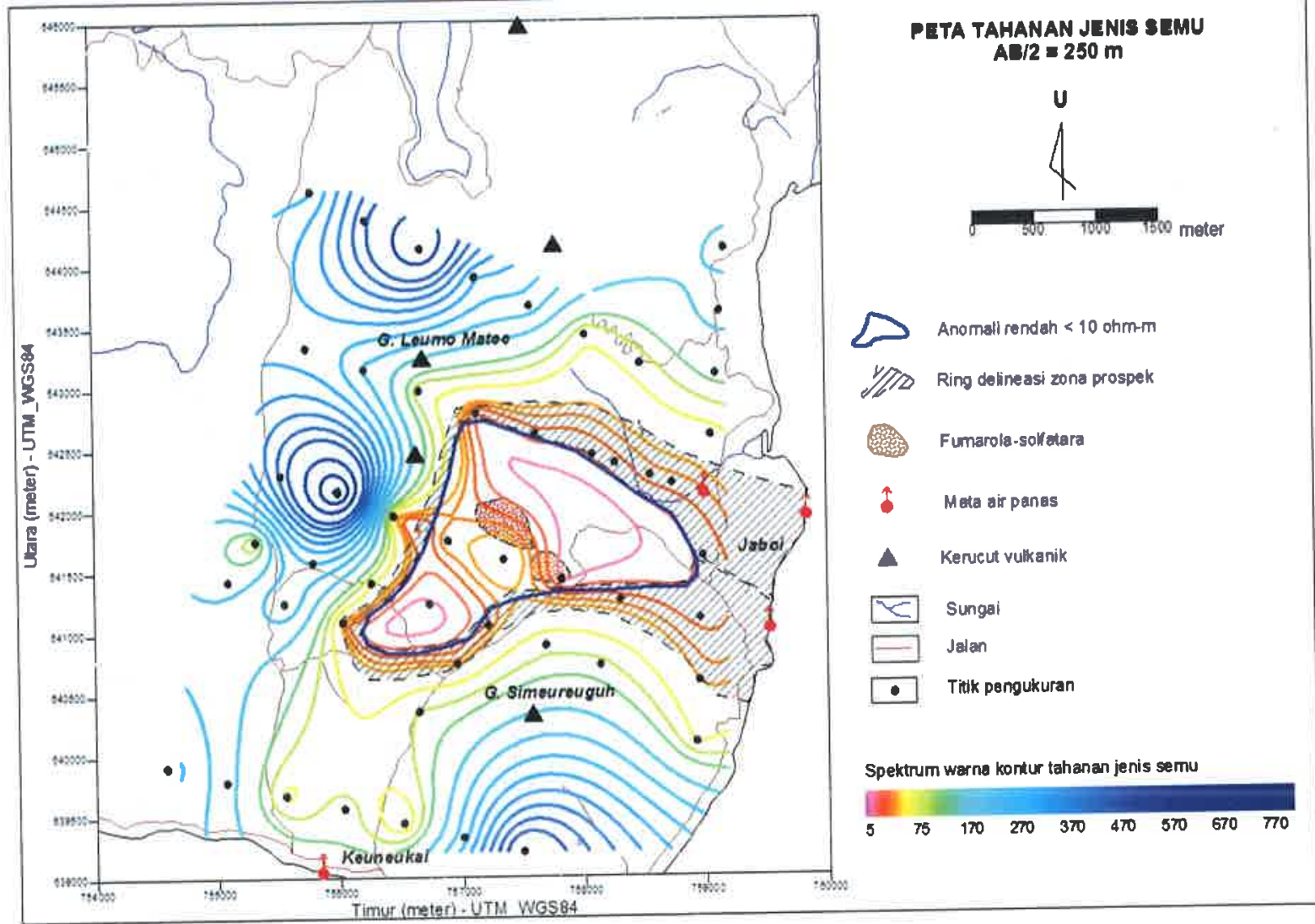

Gambar 3. Sebaran tahanan jenis semu untuk bentangan setengah arus AB/2 250 meter di daerah panas bumi Jaboi

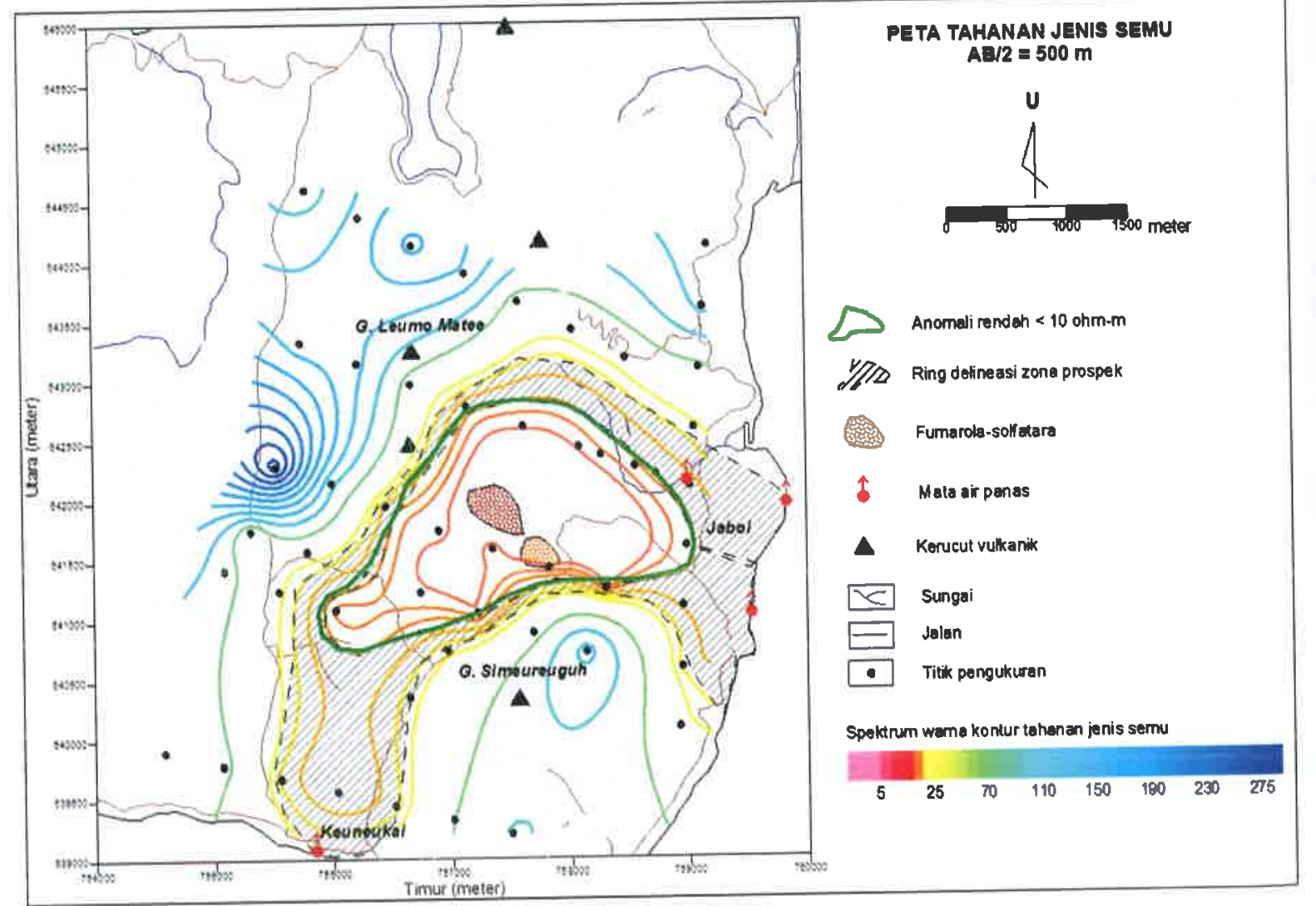

Gambar 4. Sebaran tahanan jenis semu untuk bentangan setengah arus AB/2 500 meter di daerah panas bumi Jaboi 


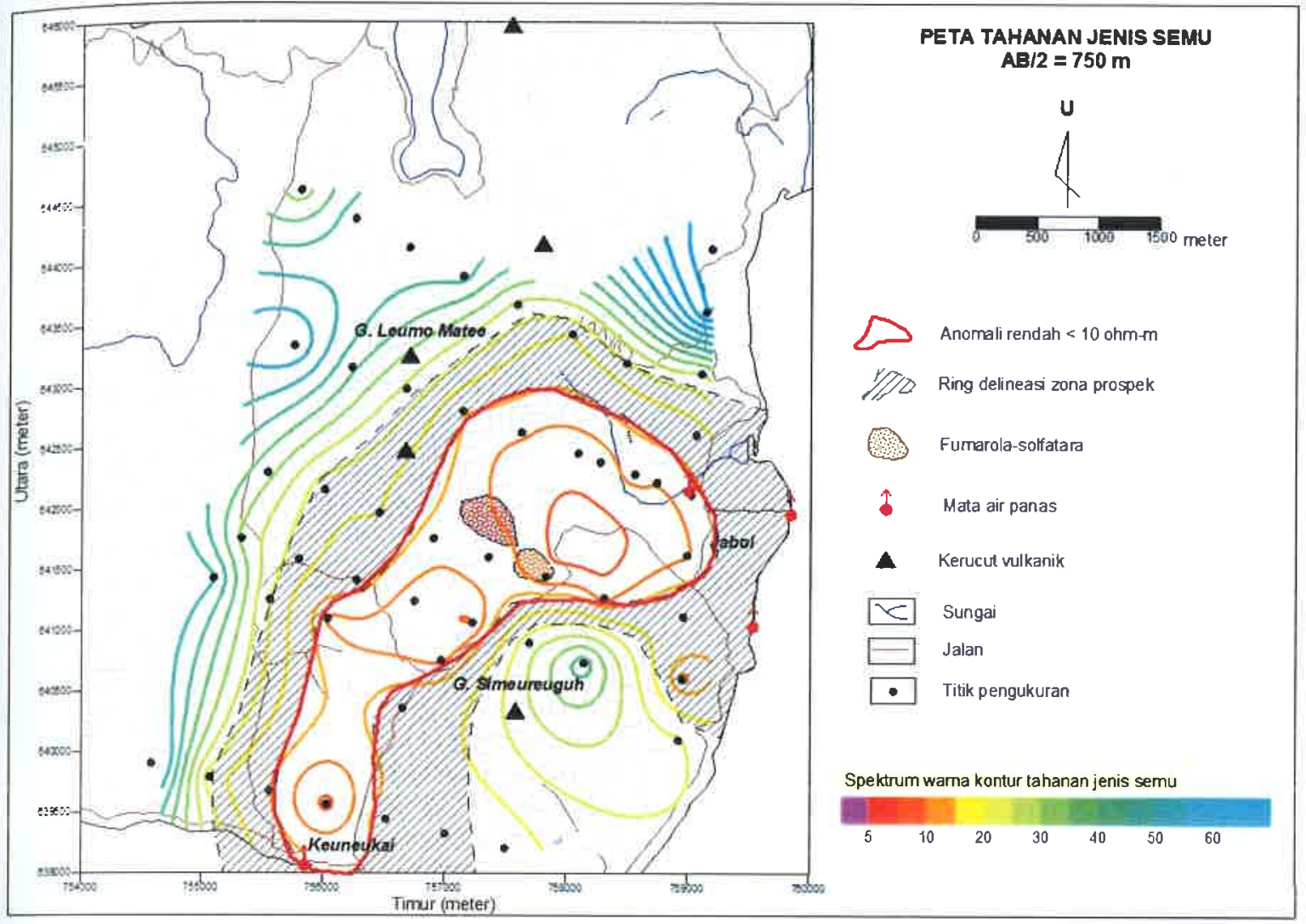

Gambar 5. Sebaran tahanan jenis semu untuk bentangan setengah arus AB/2 750 meter di daerah panas bumi Jaboi

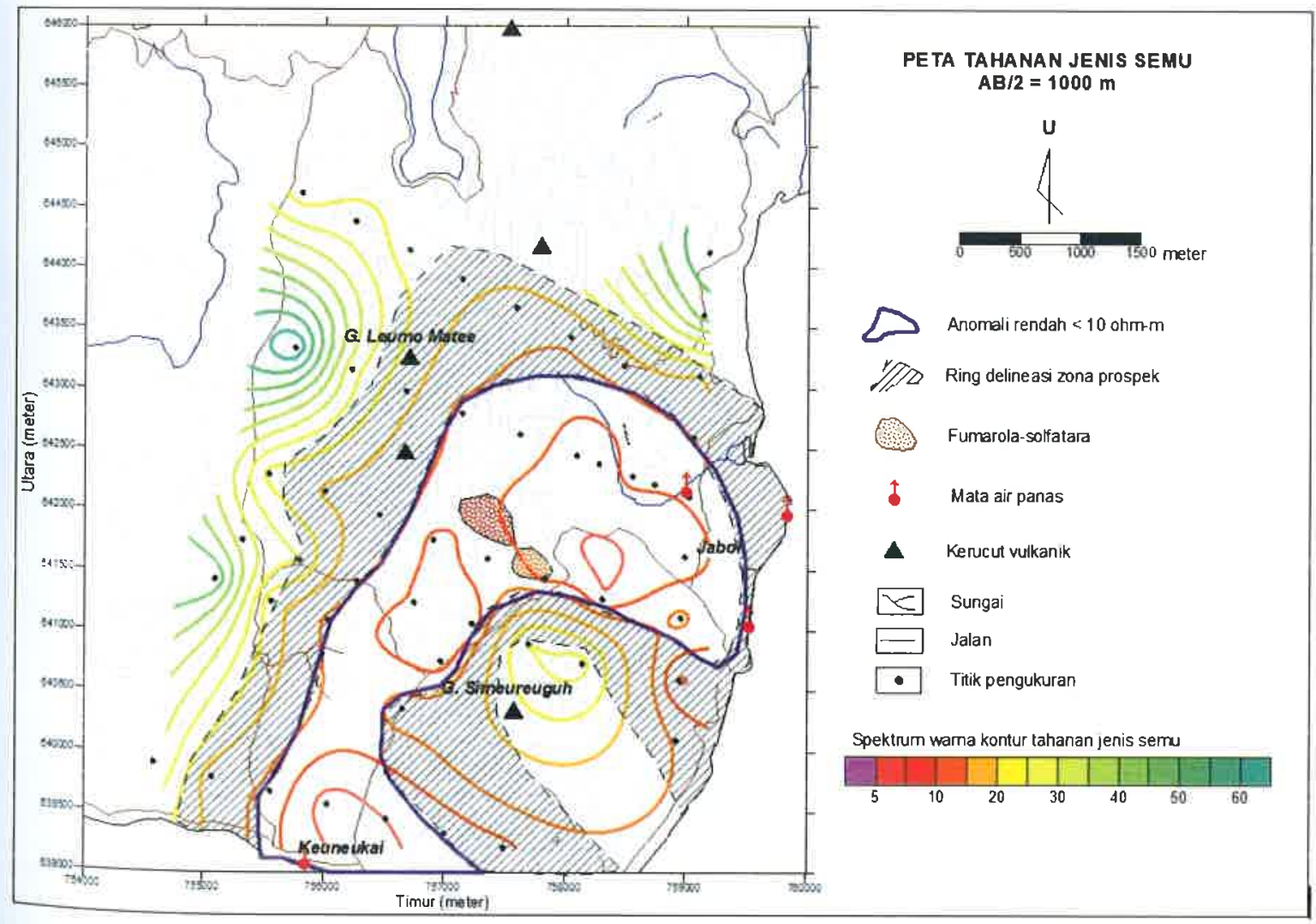

Gambar 6. Sebaran tahanan jenis semu untuk bentangan setengah arus AB/2 1000 meter di daerah panas bumi Jaboi 


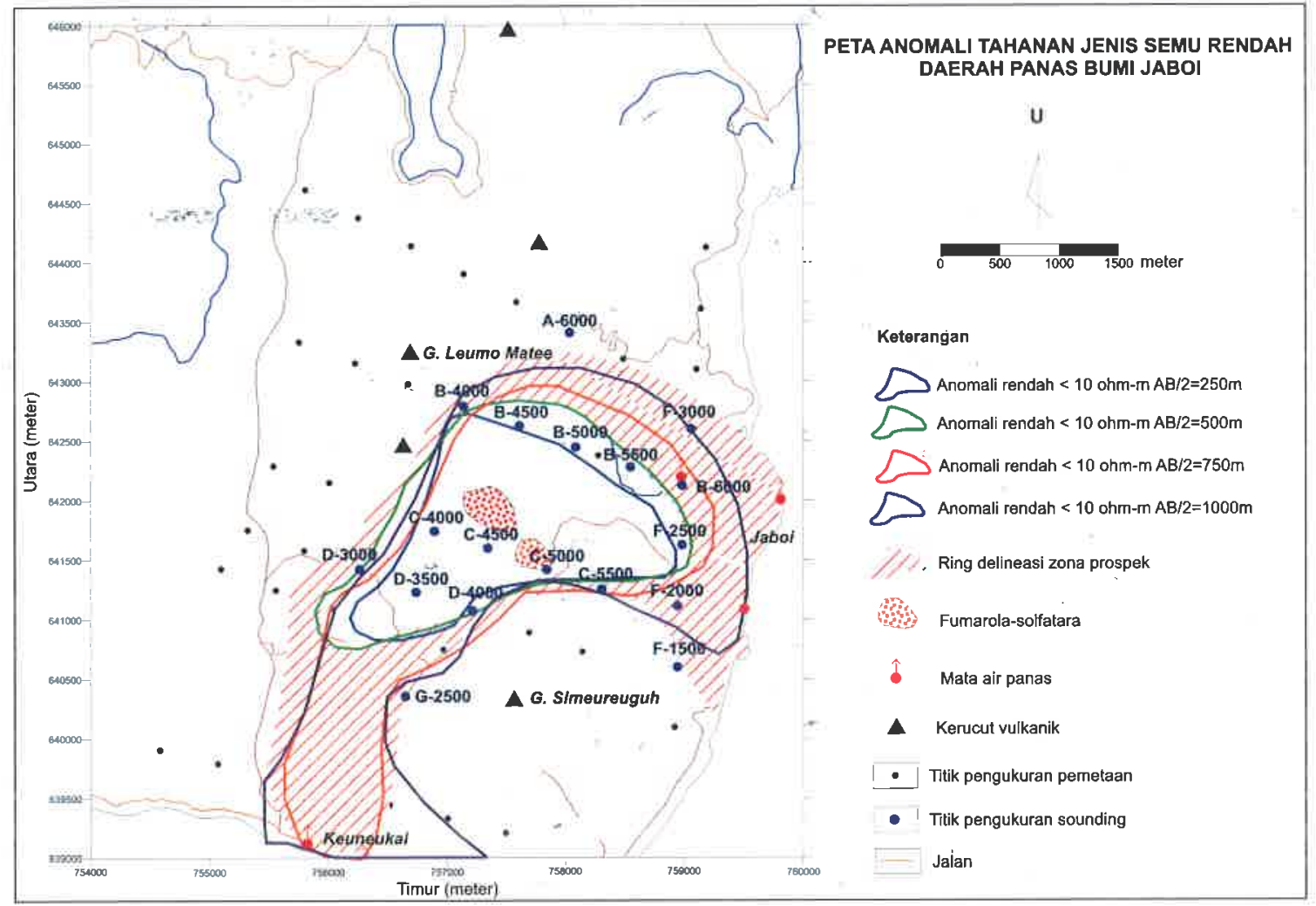

Gambar 7. Peta kompilasi anomali tahanan jenis semu rendah dan ring delineasi batas prospek Jaboi

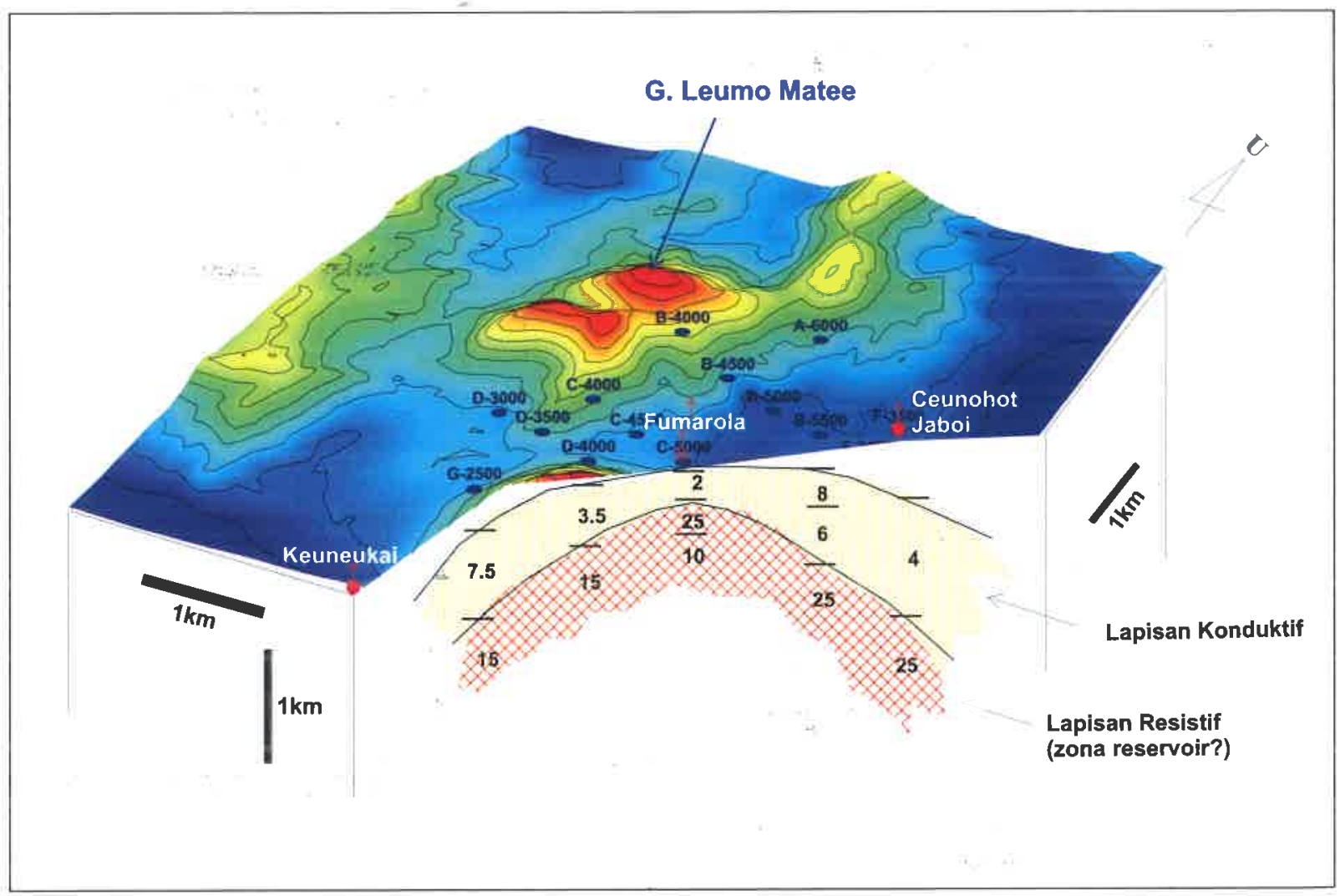

Gambar 8. Penampang model tahanan jenis (dalam Ohm-m) daerah Jaboi, diperoleh dari hasil-hasil pemodelan satu dimensi data sounding. Hasil ini memperlihatkan struktur tahanan jenis bentuk kubah, suatu bentuk yang umum ditemukan di lapangan panas bumi temperatur tinggi dalam lingkungan vulkanik. 


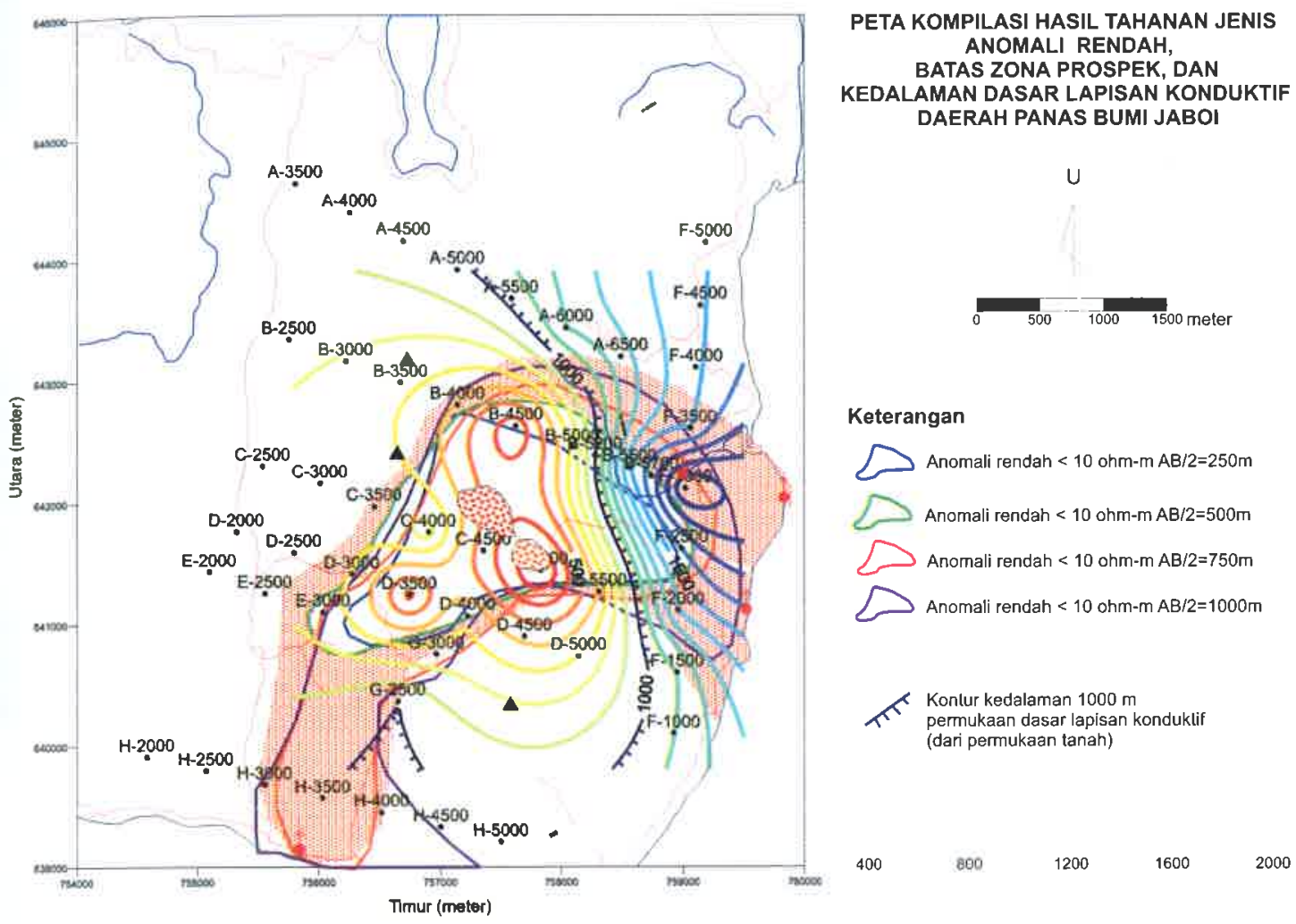

Gambar 9. Peta kompilasi hasil tahanan jenis daerah panas bumi Jaboi, memperlihatkan batasbatas anomali rendah, batas zona prospek, dan permukaan dasar lapisan konduktif.

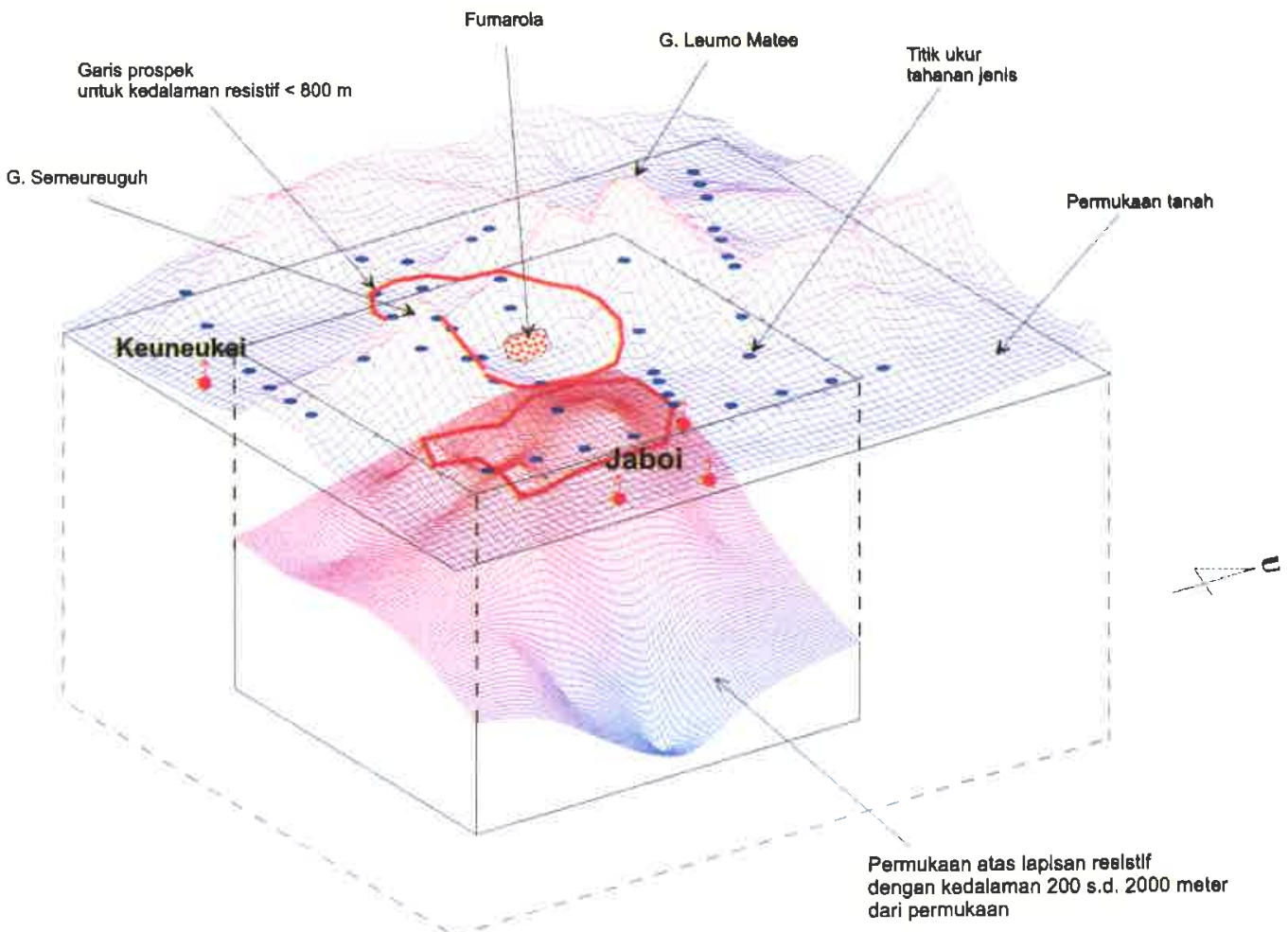

Gambar 10. Gambaran 3-dimensi dari permukaan dasar lapisan konduktif atau permukaan atas lapisan resistif daerah panas bumi Jaboi. 